\title{
Family Problems Experienced by Students of the University of Jordan
}

\author{
Faten Saad Hatahet \\ Prof. "Mohammed Amin" Hamed Alqudah \\ Educational Administration and Assets Department \\ Faculty of Educational Sciences. University of Jordan
}

doi: 10.19044/esj.2016.v12n13p145 URL:http://dx.doi.org/10.19044/esj.2016.v12n13p145

\begin{abstract}
The study has aimed at identifying the family problems among the students of the University of Jordan. The descriptive survey method has been used, and the questionnaire has been used as a tool for the study. (604) students have been selected in a stratified random manner from the University of Jordan as a sample for the study. The study results have showed that the most important and prominent family problems experienced by the University of Jordan students are: Problems in communication between family members, problems with emotional expression, lack of respect among family members, and lack of trust in the relationship with the parents. The results also showed that there are no statistically significant differences in family problems experienced by the University of Jordan students from the viewpoint of the students themselves due to the variables of gender, college, and the interaction between them both.
\end{abstract}

Keywords: Problems, family, university students

\section{Introduction}

The family is the main influences in the lives of individuals because it is the first group that is with a direct impact on them, through which the individual acquires the expertise and knowledge through the behaviors practiced and observed by him, and through the interactive family relations among its members. Many of the attitudes and actions _ positive or negative _ issued by one of the parties may be of profound effect on the other parties.

The family has a profound impact on children's behavior, attitudes and maturity of emotions. Therefore, the children's personalities are formed through experiences in which they live and through the family atmosphere that arises from the interactive family relationships. Family stability plays an important role in developing the capacity of the individual; the right 
atmosphere achieves the most important psychological and social development demands because the individual in such an atmosphere learns the social interaction, participation in everyday life as well as the personal independence.

Family stability and the sustainability of the positive relationships between family members are demand and target for all; so it is a mainstay of society. These relationships need to find some kind of rapprochement between the requirements and needs of different individuals in order to reach the point of stability. By doing this, the family atmosphere can be characterized by warmth and understanding. As a result of the different needs of individuals, a kind of conflict may arise, and then family problems that affect the stability of the family and cast a shadow over the community, appear.

If the young people in any society, according to Tarrah (2011), represent the category that is the most affected by social, economic and political changes experienced by the society, identifying the visions of young and their psychological, personal and community problems as perceived become sociological and methodical necessities, especially family problems which they suffer because of the magnitude of their effect on their behavior and performance.

The importance of the subject of study lies in that the family problems of youth represent the attention to the fate and security of society. Young people in any society are a constructive force if properly used. They are able to work and accomplish while acknowledging these young people's ability to give, and to participate positively in their community issues. The second importance is that the stage of youth is a transitional stage between childhood and adulthood. The stage of youth serves as a preparation for the social role which is being handled by the individual in his life and which starts from the family, which requires understanding the nature of the problems facing young people and then working to avoid and minimize their impact to help provide the psychological and social conditions that are suitable to take over the future role.

According to the Jabal (2012), family problems generally affect the family's ability to cope with their burden. On the other hand, the prevalence of these problems hinder the family and therefore individuals to perform the required functions such as the social interaction, and the renaissance of society scientifically and economically, which is expected to be performed by society effectively, leading to the societal equilibrium.

This is what has been reached by many of the previous studies, in study of Bushra Abu Layla (2002), it came in order to examine the relationship between parental treatment methods and conduct disorder among preparatory school students in schools of Gaza Strip, then to see what 
has been adopted by each of these variables in explaining the different number of family members, and the different level of education of both the father and the mother. It has been working with most of the public schools of preparatory stage for males in the educational directorates in Gaza and the north. A deliberate sample consisting of (167) preparatory school students who suffer from conduct disorder and a systematic random sample of normal students consisting of (170) students, have been taken. So that an equal number of normal and disturbed students of the same grade, has been taken. School counselor and a group of teachers have identified these students. The study has showed the importance of directing parents and teachers to stay away from the use of scorn, ostracism, neglect and contradiction methods of treatment because of their negative effects in forming a negative concept of the self and others, which results in manifestations of abnormal behavior of the individual. In addition to the importance of having a control authority in the family and society characterized by stability, firmness and justice to increase the religious awareness and to strengthen the values and trends that call for tolerance, brotherhood and cooperation.

Study of (Harland, P. \& Reijneveld, S. A. \& Brugman, E \& Verloove - Vanhorick, S. P. \& Verhulst, F. C., 2002) has aimed at identifying the groups of children that are the most vulnerable to behavioral or emotional problems on the basis of social and demographic characteristics, the characteristics of the family, and the events of modern life and at focusing on unemployment and divorce. Community sample has been composed of 4480 father and a mother of school-age children. Interviews have been conducted with them about demographic characteristics, conditions of their families and about the recent events in the child's life. The results have showed that the characteristics of the family and the events of recent life have been associated more strongly with the behavioral and emotional problems faced by children. The risk is somewhat higher for children who have suffered from parental unemployment and divorce recently, compared with those who suffered these events in the distant past. We conclude that children, who suffer from the recent experience that is the closest in time to unemployment or divorce of parents, are likely to have a higher rate of behavioral and emotional problems as reported by parents.

The study of Ann Najdawi (2003), has aimed at identifying the extent of crime relationship to unemployment on the one hand and to the family problems, on the other hand, from the overlap perspective of the relationship, the sample size has been 150 people. The study has found a number of findings, including: indicate the role of socialization; the study has confirmed that $32 \%$ of respondents suffer from a lack of family guidance and poor family upbringing; like giving excessive coquetry for sons and overlooking their mistakes. The study has also emphasized the importance of 
an appropriate way to deal with the social, psychological and economic problems faced by a large segment of the Jordanian society.

The study of Wael Al-Tall, Akram Al-Khatabiyah, and Ali Asiri (2004) has aimed at detecting the more family problems relating to the treatment of parents, as well as the more personal psychological problems among students Teachers College in Jizan, Saudi Arabia. The study has also aimed at detecting the effect of the variation in the characteristics of these students in terms of major, academic level and place of residence on the degree of their suffering from family problems related to the parent treatment and from personal psychological problems.

To achieve this objective, a questionnaire including -in its final form(26) problems that have branched off to: (17) family problems related to the treatment of parents (authoritarian, rejection, discrimination, and disagreements), and (9) personal psychological problems. The study sample has consisted of 365 students. Search results have revealed that the most of suffering of students of Teachers College in Jizan has been of (7) family problems; all of which relate to authoritarianism and parental rejection, and of (6) personal psychological problems. The study has also revealed that the students who live in the city are relatively more suffering from family problems related to parental treatment, at the level of overall degree of problems, than the students who live in the village.

The study of (Gover, R. \& Kaukinen, Catherine \& Fox, A., 2008) has shown that the violence in relationships is a serious social problem among adolescents and young adults. The research deals with the relationship between exposure to violence in the family and violence on others. The research also deals with gender differences in the relationship between exposure to physical and psychological violence during childhood and committing the assault and abuse. Data have been collected from a sample of about 2,500 university students of the two universities; Southern and Eastern. The search results indicate that the exposure to violence in childhood is a constant indicator of involvement in violent relationships for males and females.

The study of Yasser Ismail (2009) has aimed at identifying the most common and important behavioral problems among children deprived of family care. And also it has aimed at identifying how different those problems among the disadvantaged depending on variable of the period of loss, its type, age of the child during the loss, gender and academic level. The sample of the study has been (133) boys and girls between the ages of 10-16 years from accommodation establishments in the Gaza Strip.

The study has concluded results, including: 1- the most of the problems afflicting deprived of a family environment are:"bad behavior, neuroses, depression, emotional symptoms" primarily, and "problems with 
friends and increase of movement" Secondly. 2- the children who have been deprived of the fathers by divorce have a lot of problems with their peers according to the opinion of the mother and child alike, while the children who lost their parents by death have achieved a lesser degree in behavioral problems, especially with their peers.

The aim of the study of Hammoud (2010) is to identify the parental treatment methods, which are remembered by the normal juvenile and delinquents as well as the differences between normal and delinquent in parental treatment methods as remembered by juveniles and the differences between fathers and mothers in parental treatment methods as remembered by the children. The sample of the study has been (275) members of normal ones and delinquents.

Al Masmari's study (2012) has aimed at investigating the effect of family problems on the socialization methods for children. It has been applied to a sample of juvenile delinquents in the Al Bayda city in Libya. The results have showed a correlation between family problems and its impacts on socialization in contemporary Libyan family in terms of its relations to juvenile delinquency.

Abdulkareem's study (2012) has aimed at recognizing the nature of relationships within the family, in the light of social variables in the city of Marj in Libya (the husband and wife relationship, the father and children relationship, the mother and children relationship, siblings' relationship) and in light of the relationship of variables of the educational level the head of household (husband, father), educational level of the female headship (wife, mother), the economic level of the family, family size, the work of female headship (wife, mother), and the number of hours of watch satellite channels by the family members. The results have showed that there is a statistically significant negative correlation in the nature of relationships within the family, educational level and hours of watch satellite channels.

From this standpoint and from the findings of previous studies, this research seeks at defining the concept of family problems briefly, and works on display some of these problems, specifically those suffered by the students of the University of Jordan.

The problem of the study and questions:

The two researchers have observed through their work that the behaviors of university students are basically caused by the weakness of family upbringing, which has led to problems in personality such as: poor self-confidence, inability to make decisions. It has been also noted a weakness among the students in dealing with the problems they face and any new problems. This is what the results of several studies pointed out to, like study of Bushra Abu Layla (2002) and study of Abdulkareem (2012). Therefore, the problem of current study is the revealing of family problems 
experienced by the University of Jordan students through the following questions:

1. What are the family problems experienced by the University of Jordan students from the viewpoint of the students themselves?

2. Are there statistically significant differences at level of significance $(\alpha \leq 0.05)$ in the family problems of the University of Jordan students from the viewpoint of the students themselves, due to gender and college?

Importance of the study: it is hoped that the following entities take advantage from the results of this study:

1. University young category is to identify the family problems they face and how to deal with.

2. Jordanian universities are to identify the family problems of their students and to adopt the necessary programs to address and deal with them.

3. The researchers, since the study may raise their desire to further research on the subject of family problems experienced by students of the University of Jordan.

The objective of the study: The main objective of the study is to identify the family problems experienced by students of the University of Jordan.

The term of survey and defining it procedurally later:

Family problem procedurally: An imbalance that affects the family so that it hinders the process of communication between its members or prevents individuals from carrying out their duties towards the family or the community.

The study limits: The study has included the following limits:

- Human limits: This study has been limited to the University of Jordan students.

- Temporal limits: The academic year (2015-2016).

- Spatial limits: The University of Jordan. tool.

Determinants of the study: The psychometric properties of the study

Methodology of the study: the analytical survey method will be used for the detection of family problems experienced by students of the University of Jordan.

The study population: The study population has consisted of all students of University of Jordan for the academic year (2015- 2016), totaling $(36,699)$ students (Ministry of Higher Education, 2014).

The study sample: The study sample has been chosen in a stratified random manner that represented the University of Jordan students and study sample has consisted of (604) students; Table 1 shows the distribution of the study sample by levels of variables. 


$\begin{array}{lccc}\text { Variable } & \text { Level } & \text { No. } & \text { Total } \\ \text { Gender } & \text { Male } & 203 & 604 \\ & \text { Female } & 401 & \\ \text { College } & \text { Humanitarian } & 372 & 604 \\ & \text { Scientific } & 213 & \end{array}$

The study tool: the two researchers have developed a questionnaire to identify family problems suffered by the Jordanian university students. The theoretical literature related to the subject of family problems and theses related, such as Yasser Ismail's study (2009) have been used to identify the most important and common behavioral problems among children deprived of family care. The questionnaire has included 20 items. Each item has been given a graded weight on the triple scale of Likert.

The degree of suffering of Jordanian university students from family problems have been determined by dividing the degrees of estimate into five levels (agree strongly - agree - neutral - not agree - not agree strongly) depending on the criterion used to judge the degree of estimate:

- Low, if the arithmetic average value is less than (2.33)

- Medium, if the arithmetic average value is greater than or equal to (2.33) and less than (3.67)

- High, if the value of the arithmetic average is greater than or equal to (3.67).

It is by dividing the distance between the lower mark (1) and the biggest mark (5) into three equal distances.

\section{The study tool}

To verify the veracity of the questionnaire, the virtual honesty has been verified by viewing it to ten arbitrators who are specialists and experts in the field of educational administration and assets. The approval of (80\%) of the arbitrators on the content of each item has been considered an indication of the honesty of study, and thus it has been retained. Some arbitrators have expressed their suggestions to amend and re-formulate some items.

\section{Reliability of study tool}

Study tool has been applied to (27) students from within and outside the study population; Reliability coefficient has been calculated using Cronbach's alpha equation and has reached (0.87). This value is an indication of validity of the tool to be applied. 


\section{Results of the study and discussing them}

The first question: What is the level of the family problems of the University of Jordan students from the viewpoint of the students themselves?

To answer the question, the arithmetic averages and standard deviations for the family problems experienced by the University of Jordan students from their point of view, have been calculated; Table 2 shows the results.

Table (2): The arithmetic averages and standard deviations for the family problems experienced by the University of Jordan students from their point of view

\begin{tabular}{|c|c|c|c|}
\hline $\begin{array}{c}\text { Estimatio } \\
n\end{array}$ & $\begin{array}{c}\text { Rankin } \\
\text { g }\end{array}$ & $\begin{array}{l}\text { Standard } \\
\text { deviation }\end{array}$ & $\begin{array}{c}\text { Arithmeti } \\
\text { average }\end{array}$ \\
\hline High & 1 & 0.90 & 4.13 \\
\hline Moderate & 2 & 1.35 & 3.26 \\
\hline Moderate & 3 & 1.31 & 3.07 \\
\hline Moderate & 4 & 1.30 & 2.53 \\
\hline Moderate & 5 & 1.33 & 2.50 \\
\hline Moderate & 6 & 1.27 & 2.43 \\
\hline Moderate & 7 & 1.32 & 2.41 \\
\hline Moderate & 8 & 1.29 & 2.38 \\
\hline Moderate & 9 & 1.21 & 2.37 \\
\hline $\begin{array}{c}\text { Moderat } \\
e\end{array}$ & 10 & 1.26 & 2.35 \\
\hline $\begin{array}{c}\text { Moderat } \\
e\end{array}$ & 11 & 1.37 & 2.33 \\
\hline Low & 12 & 1.28 & 2.32 \\
\hline Low & 13 & 1.33 & 2.29 \\
\hline Low & 14 & 1.29 & 2.24 \\
\hline Low & 15 & 1.25 & 2.23 \\
\hline Low & 15 & 1.26 & 2.23 \\
\hline Low & 15 & 1.31 & 2.23 \\
\hline Low & 16 & 1.29 & 2.22 \\
\hline Low & 17 & 1.38 & 2.21 \\
\hline Low & 18 & 1.31 & 2.19 \\
\hline $\begin{array}{c}\text { Moderat } \\
e\end{array}$ & & 0.76 & 2.49 \\
\hline
\end{tabular}

Paragraph

There is an understanding between my parents

I talk with my study colleagues more than with my father

I talk with my study colleagues more than with my mother

Kins of my father intervene in matters of my family

Kins of my mother intervene in matters of my family

I ignore my parents' orders with respect to my decisions that I am taking

There is an intellectual gap between me and my father

There is an intellectual gap between me and my mother

I ignore my mother's orders with respect to my decisions that I am taking

My father blames my mother whenever I am exposed to a problem

There is no dialogue between me and my father

My mother often complains of problems within the family

There is a problem in terms of the difference in the level of education between my parents

My father tends emotionally to my brothers more than my sisters

My mother tends emotionally to my brothers more than my sisters

There is no respect among my family members

My relationship with my mother Lacks to trust

My relationship with my father lacks to trust

There are no feelings or appreciation between my parents

There is no dialogue between me and my mother

Total 
As shown in the table (2), paragraph (there is understanding between the parents) has a high degree of estimation. As for the rest of the paragraphs, the degree of estimation of (10) clauses was moderate, and the degree of estimation of (9) clauses was low. The largest estimation was for clause (there is understanding between the parents) whose the arithmetic average has a value (4.13) with a standard deviation of (0.90). This shows that this clause does not pose a problem among the University of Jordan students from the viewpoint of the students themselves, because it is positive and its estimation is high; it is perhaps due to the nature of Jordanian families that are trying to maintain its general existence and the most important pillars which is understanding among its members. This explains that the majority of problems facing the students have been estimated by moderate and low degrees.

The least estimation was for clause (there is no dialogue between me and my mother), whose the arithmetic average has a value (2.19) with a standard deviation of (1.31). It could be attributed to the strength of the relationship between the children and the mother particularly and characteristically. This is due to the significant role the mother plays in the lives of their children and also to the nature of the Jordanian family in which the mother is usually more inherent to the child than the father. The degree of total estimation of family problems experienced by the University of Jordan students from the viewpoint of the students themselves has been moderate and value of its arithmetic mean has been (2:49) with a standard deviation of (0.76). This is due to the Family upbringing emanating from the values and traditions that are interested in establishing the correlation between family members to keep the most important part of the community (family).

This result is similar to the result of Bushra Abu Layla study (2002), (Harland, P. \& Reijneveld, SA \& Brugman, E \& Verloove - Vanhorick, SP \& Verhulst, FC, 2002), Ann Najdawi (2003), Gopher and Kwakann and Catherine and Fox (Gover, R. \& Kaukinen, Catherine \& Fox, A., 2008), Yasser Ismail (2009), Masmari (2012), and Abdul Karim (2012), which has showed the role of upbringing, family bonding and mutual respect among family members in the problems facing the students.

Second question: Are there significant differences at the level of significance $(\alpha \leq 0.05)$ in the level of family problems experienced by the University of Jordan students from the viewpoint of the students themselves, attributed to the variables of gender and college?

To answer this question, Arithmetic average and standard deviations of the family problems experienced by the University of Jordan students from the viewpoint of the students themselves have been calculated 
according to the variables of gender and college; Table 3 shows the results of that.

Table 3: Arithmetic average and standard deviations of the family problems experienced by the University of Jordan students from the viewpoint of the students themselves according to the variables of gender and college

$\begin{array}{cc}\begin{array}{c}\text { Standard } \\ \text { deviation }\end{array} & \begin{array}{c}\text { Arithmetic } \\ \text { average }\end{array} \\ 0.92 & 2.60 \\ 0.74 & 2.80 \\ 0.75 & 2.36 \\ 0.86 & 2.65 \\ 0.69 & 2.38 \\ 0.67 & 2.46 \\ 0.75 & 2.45 \\ 0.69 & 2.41 \\ 0.78 & 2.45 \\ 0.71 & 2.57 \\ 0.73 & 2.39 \\ 0.76 & 2.49\end{array}$

$\begin{array}{lc}\text { College } & \text { Gender } \\ \text { Humanities } & \text { Male } \\ \text { Scientific } & \\ \text { Medical } & \\ \text { All } & \\ \text { Humanities } & \text { female } \\ \text { Scientific } & \\ \text { Medical } & \\ \text { All } & \\ \text { Humanities } & \text { All } \\ \text { Scientific } & \\ \text { Medical } & \\ \text { All } & \end{array}$

From Table 3, it is noted that there is a virtual difference in mathematical means values for the family problems experienced by the University of Jordan students from the viewpoint of the students themselves according to the variables of gender and college.

To find out if these differences are statistically significant, an analysis of binary variance has been made; Table 4 shows the results of that.

Table (4): The results of analysis of binary variation of the impact of gender and College on family problems experienced by the University of Jordan students from the viewpoint of the students themselves

$\begin{array}{cccccc}\begin{array}{c}\text { Level of } \\ \text { significance }\end{array} & \begin{array}{c}\text { The } \\ \mathrm{P} \\ \text { value }\end{array} & \begin{array}{c}\text { Average } \\ \text { squares }\end{array} & \begin{array}{c}\text { Degrees } \\ \text { of } \\ \text { freedom }\end{array} & \begin{array}{c}\text { Sum of } \\ \text { squares }\end{array} & \begin{array}{c}\text { Source of } \\ \text { variation }\end{array} \\ .217 & 1.525 & .864 & 1 & .864 & \begin{array}{c}\text { Gender } \\ \text { College } \\ .114\end{array} \\ 2.175 & 1.232 & 2 & 2.464 & \begin{array}{c}\text { Gender } \\ \text { College }\end{array} \\ .435 & .833 & .472 & 2 & .943 & \text { Fault } \\ & & .566 & 598 & 338.756 & \text { Total }\end{array}$

From Table 4, it is noted that there have been no statistically significant differences at the level of significance $(\alpha \leq 0.05)$ in the family problems facing the University of Jordan students from the viewpoint of the students themselves attributed to the variables of sex, college, and the interaction between them both; for the gender variable, this result may be attributed to that the impact of family problems on both genders in the 
Jordanian family is alike, which confirms the participation of all members of the family in maintaining family bonding. For the variable of college, the result may be attributed to that all students at the university with diverse intellectual classes are subject to the same customs, values and traditions that dominate our society, which has reduced the differences between the responses of students of humanitarian, scientific and medical colleges.

This result has agreed with the result of the study of Mohammad Hammoud (2010) that has showed that there have been no statistically significant differences in parental treatment methods according to gender variable among delinquents of respondents. But this result has disagreed with the result of Yasser Ismail's study (2009), that there are significant differences between the two genders from the point of view of the child in the psychological problems in favor of males. Some previous studies did not address to discuss whether the gender variable leads to statistically significant differences.

Recommendations: In the light of the results of the study, the researcher has adopted a number of recommendations including:

- Universities are to adopt programs that help students deal with the Family problems so as to be provided in all stages of university studies with a focus on providing special programs in this regard to first-year students in particular.

- Providing advanced training programs for faculty members to help students deal with the family problems.

- Universities, especially the educational colleges are to review the socialization programs and to work to develop programs that enhance students' ability to deal with family problems through family and school institutions.

- Enhancing the coordination between universities and centers of consulting, training and development, public and private, to build programs that help students in dealing with family problems.

\section{References:}

\section{Arabic References}

Abu Laila, Bushra (2002), Parental treatment methods as perceived by the children and their relation to the disorder of behavior among middle school students in schools of governorates of Gaza, MA, the Islamic University, Gaza, Palestine.

Ismail, Yasser (2009), Behavioral problems among children deprived of their family environment, MA, the Islamic University, Gaza, Palestine.

Al Tall, Wael and Khatabiyah, Akram and Asiri, Ali, (2004), Family and personal problems among students of Teachers College in Jizan, Saudi 
Arabia, Journal of Mutah for Research and Studies, University of Mutah 7 (19) 87 to 112.

Jabal, Abdel Nasser Awad Ahmed, (2012), Family disputes from the social service perspective, Dar Al-Wafa for printing and publishing: Alexandria.

Hammoud, Mohammed Al Sheikh (2010), Parental treatment methods as perceived by normal and delinquents children - Comparative Empirical Study - Governorate of Damascus, Damascus University Journal 4 (26) 17 to 56.

Tarrah, Ali Ahmed (2003), Personal and community problems of young of Kuwaiti universities, Comparative Empirical Study, Humanities and Social Sciences Journal 2(19) 17 to 69.

Abdul Karim, Adel Mohamed Ali (2012), Relations within the family in light of some social variables, Thesis (PhD) - Mansoura University, Faculty of Literature, Department of Sociology.

Afifi, Abdul Khaliq Mohammed (2011), Building the family and contemporary family problems, modern university office: Egypt.

Masmari, Riham Faraj Ibrahim (2012), The impact of family problems on socialization methods for children, Thesis (PhD) - Ain Shams University, Faculty of Literature, Department of Sociology.

Al Najdawi, Ann Musa, (2003), Crime and its relation to unemployment and family problems, Thesis, University of Jordan, Amman, Jordan.

\section{Foreign References}

Angela R. Gover ,Catherine Kaukinen, Kathleen A. Fox,(2008) ,The Relationship Between Violence in the Family of Origin and Dating Violence Among College Students, online research, Retrieved June 16, 2015,from http://jiv.sagepub.com/content/early/2008/03/18/0886260508314 330.short

Harland, P. \& Reijneveld, S. A. \& Brugman, E \& Verloove-Vanhorick, S. P.\& Verhulst, F. C., (2002), Family factors and life events as risk factors for behavioral and emotional problems in children, 11 (4), 176-184, [Available online], $\quad$ Retrieved June 2015 from http://link.springer.com/article/10.1007/s00787-002-0277-z 